\title{
Assessment of the Effectiveness of Medical Education on the Moodle e-Learning Platform
}

\author{
Wiesław Półjanowicz ${ }^{1}$, Grzegorz Mrugacz², Michał Szumiński ${ }^{3}$, \\ Robert Latosiewicz ${ }^{4}$, Alina Bakunowicz-Łazarczyk ${ }^{3}$, Anna Bryl ${ }^{3}$, \\ Małgorzata Mrugacz ${ }^{3}$
}

${ }^{1}$ Department of Didactics and Modern Technologies in Education, University of Bialystok, Poland

2 Center for Reproductive Medicine "Bocian", Bialystok, Poland

3 Department of Pediatric Ophthalmology, Medical University of Bialystok, Poland

${ }^{4}$ Department of Rehabilitation and Physiotherapy, Medical University of Lublin, Poland

\begin{abstract}
This paper presents an analysis of learning effectiveness for the courses "Selected issues in visual rehabilitation" and "Ophthalmology and ophthalmic nursing" taught in the years 2009-2011 at the Medical University of Bialystok, Poland. We compared the effectiveness of traditional and distance learning methods; an e-learning platform was implemented experimentally for the purpose of this study. We assessed the usefulness of online learning in terms of organization, knowledge gained and students' satisfaction with the course. The study was conducted among 75 second year master degree students in the nursing field in the academic years 2009/2010 and 2010/2011. The students were divided into two groups. For the study group of 39 persons $(52 \%)$, lectures and seminars took place on an e-learning platform, while 36 persons (48\%) in the control group attended traditional classes. $80 \%$ of students in the e-learning group and $89 \%$ of students in the traditional group assessed the organization of both forms of courses positively. The fact that the majority of students in both the e-learning (89\%) and traditional classes (86\%) gave positive feedback indicates that for both forms there was a high level of content and technical preparedness. The mean scores of the final exam for both courses were $82 \%$ in the e-learning group and $79 \%$ in the traditional group in the years 2009 2011. The above results show that both forms of learning are equally effective.
\end{abstract}

\section{Introduction}

A growing number of people are interested in distance learning. Widespread access to computers and the Internet means that more and more people can participate in the e-learning process. The search for new methods of learning and teaching has caused distance learning to be increasingly used at the university level. E-learning is independent of place 
Wiestaw Pótjanowicz et al.

and time, and the teachers determine the rules of conduct and access to classes. E-learning does not intend to replace traditional forms of education, but it is a good way to supplement and widen knowledge transfer (Allan, 2007; Arbaugh et al., 2010; Bramley, 2001; Smith et al., 2008).

The availability of a number of distance learning programs enables the development of modern e-learning courses, which are placed on an accessible platform in accordance with SCORM, AICC, and IMS (Piskurich, 2003; Waćkowski et al., 2007). With these tools, interactive tests, quizzes and tasks to test students' knowledge can be created.

This study of learning effectiveness in the courses "Selected issues in visual rehabilitation" and "Ophthalmology and ophthalmic nursing" aimed at evaluation of the effectiveness of nursing education supplemented by distance learning techniques. The Bioethics Committee of the Medical University of Bialystok approved the study (consent No. R-I-002/338/2009).

\section{$\operatorname{Aim}$}

The courses "Selected issues in visual rehabilitation" and "Ophthalmology and ophthalmic nursing" were taught experimentally in a complementary e-learning system during the 2009-2011 academic years. The lectures and seminars were conducted on-line, but practical classes were taught traditionally. Students who participated in the e-learning method had free access to the distance-learning platform (Moodle) and to the courses. Students had continuous and unlimited access to the teaching materials on the platform, but the teacher responsible for the course determined the order of the topics and the period of their availability. The final exam was, however, in "traditional" form, as laid out in the Regulations of the Medical University of Bialystok.

\section{Material and Methods}

The study was conducted with a group of 75 second year master degree nursing students enrolled in the courses "Selected issues in visual rehabilitation" and "Ophthalmology and ophthalmic nursing" during the years 2009-2011. The students were divided into two groups. In the control group (36 people), lectures and seminars were taught traditionally. In the study group (39 people), lectures and seminars took place on the e-learning platform MOODLE, ver. 1.9 (Rice, 2010) (Figure 1), where all didactic ma- 
Assessment of the Effectiveness of Medical Education on the Moodle...

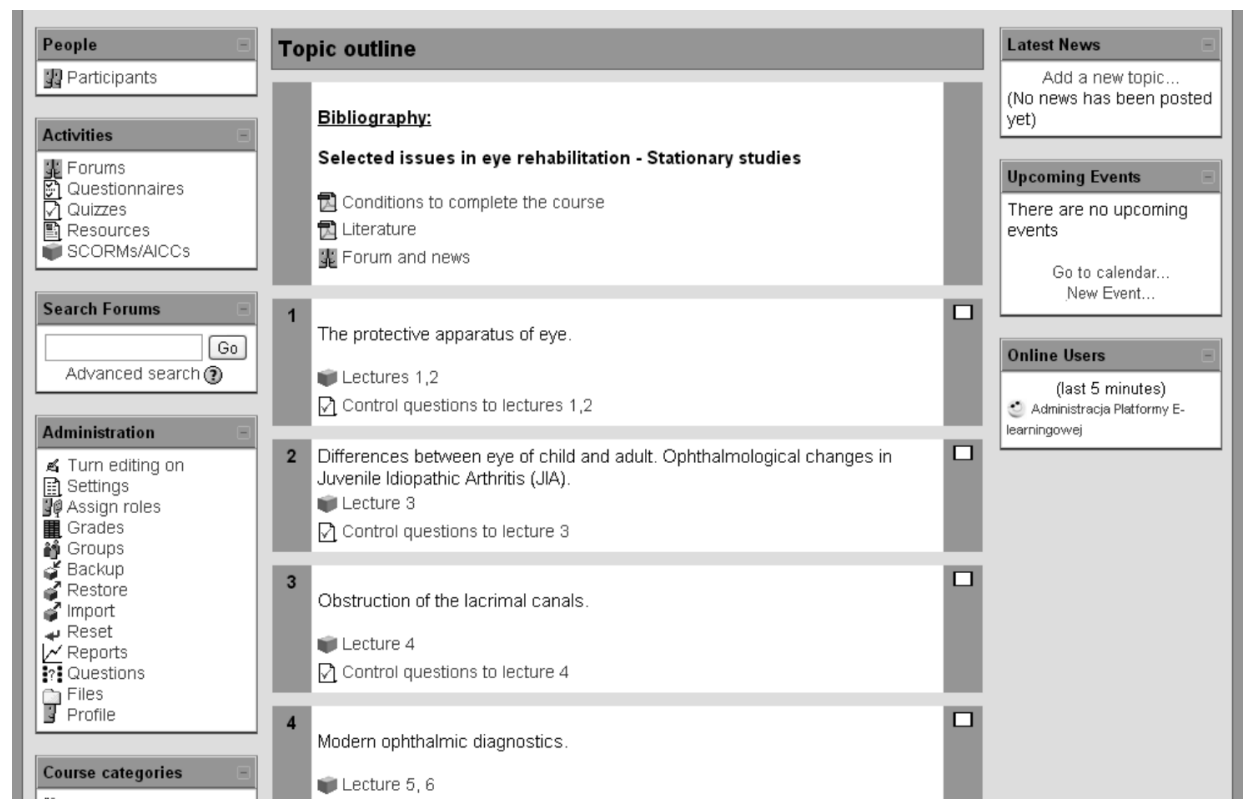

Figure 1. Screenshot of e-learning course "Selected issues in visual rehabilitation"

terials, prepared for distance learning were available. Every student from the study group had 24-hour access to didactic materials, including multimedia, knowledge assessment tests and evaluation forms. Students' activity (e.g. lecture reading, watching multimedia materials or completing an evaluation form) was registered and a log of individual achievements was created. The order of didactic topics and the period of their availability was supervised by academic teachers responsible for particular subjects.

A final assessment of both courses (e-learning and traditional) was conducted traditionally in the form of a multiple-choice test at the same time for both groups. The final exam scores for both groups were compared in order to analyze the level of knowledge gained. At the end of the cycle of classes but before completion of the final exam, students in both groups filled an evaluation questionnaire pertaining to their opinions of the course, the level of their satisfaction with the course, and the organization of classes.

\section{Results and Discussion}

This study on learning effectiveness for the courses "Selected issues in visual rehabilitation" and "Ophthalmology and ophthalmic nursing" in- 
Wiestaw Pótjanowicz et al.

Table 1. Final exam scores (in \%) for the study and the control groups in the course "Selected issues in visual rehabilitation" in the academic years 2009-2011

\begin{tabular}{|c|c|c|c|c|c|c|c|c|c|c|}
\hline \multirow[b]{2}{*}{ Academic year } & \multirow[b]{2}{*}{ Group } & \multicolumn{9}{|c|}{ Parameter } \\
\hline & & $\mathrm{n}$ & $\begin{array}{l}\text { mean } \\
\text { score } \\
\bar{x}\end{array}$ & $\mathrm{SD}$ & Min. & $\mathrm{Q}_{1}$ & $\mathrm{Me}$ & $\mathrm{Q}_{3}$ & Max. & $p$ \\
\hline \multirow{2}{*}{$2009 / 2010$} & Study & 22 & $81.8 \%$ & $9.1 \%$ & $65 \%$ & $75 \%$ & $80 \%$ & $90 \%$ & $100 \%$ & \multirow{2}{*}{0.004} \\
\hline & Control & 17 & $71.8 \%$ & $10.4 \%$ & $55 \%$ & $65 \%$ & $70 \%$ & $80 \%$ & $90 \%$ & \\
\hline \multirow{2}{*}{$2010 / 2011$} & Study & 17 & $86.5 \%$ & $8.2 \%$ & $75 \%$ & $80 \%$ & $90 \%$ & $90 \%$ & $100 \%$ & \multirow{2}{*}{0.34} \\
\hline & Control & 19 & $83.9 \%$ & $5.4 \%$ & $75 \%$ & $80 \%$ & $85 \%$ & $90 \%$ & $90 \%$ & \\
\hline
\end{tabular}

Table 2. Final exam scores (in \%) for the study and the control groups in the course "Ophthalmology and ophthalmic nursing" in the academic years 2009-2011

\begin{tabular}{|c|c|c|c|c|c|c|c|c|c|c|}
\hline \multirow[b]{2}{*}{ Academic year } & \multirow[b]{2}{*}{ Group } & \multicolumn{9}{|c|}{ Parameter } \\
\hline & & $\mathrm{n}$ & $\begin{array}{l}\text { mean } \\
\text { score } \\
\bar{x}\end{array}$ & $\mathrm{SD}$ & Min. & $\mathrm{Q}_{1}$ & $\mathrm{Me}$ & $\mathrm{Q}_{3}$ & Max. & $p$ \\
\hline \multirow{2}{*}{$2009 / 2010$} & Study & 22 & $78.0 \%$ & $13.2 \%$ & $47 \%$ & $71 \%$ & $79 \%$ & $89 \%$ & $95 \%$ & \multirow{2}{*}{0.62} \\
\hline & Control & 17 & $74.9 \%$ & $14.9 \%$ & $47 \%$ & $63 \%$ & $79 \%$ & $89 \%$ & $95 \%$ & \\
\hline \multirow{2}{*}{$2010 / 2011$} & Study & 17 & $79.4 \%$ & $3.3 \%$ & $72 \%$ & $78 \%$ & $78 \%$ & $83 \%$ & $83 \%$ & \multirow{2}{*}{0.04} \\
\hline & Control & 19 & $81.6 \%$ & $2.7 \%$ & $78 \%$ & $78 \%$ & $83 \%$ & $83 \%$ & $83 \%$ & \\
\hline
\end{tabular}

cluded relatively equal groups of students participating through the use of e-learning and according to the traditional method. 39 persons were $(52 \%)$ in the e-learning group and 36 students (48\%) belonged to the traditional learning methods group. Table 1 presents the mean final exam scores for the course "Selected issues in visual rehabilitation" of the students in the e-learning and traditional groups in the academic years 2009-2011. Table 2 presents the mean final exam scores for the course "Ophthalmology and ophthalmic nursing" in both groups during the same period.

It can be concluded that the mean scores obtained on the final exams during 2009-2011 had an upward trend for both courses in both groups of students.

In the academic year 2009/2010, the mean final exam score for the course "Selected issues in visual rehabilitation" was $81.8 \%( \pm 9.1 \%)$ in the 
e-learning group and $71.8 \%( \pm 10.4 \%)$ in the traditional group. The differences between these mean scores were statistically significant $(p<0.05)$. In 2010/2011 mean scores were $86.5 \%( \pm 8.2 \%)$ and $83.9 \%( \pm 5.4 \%)$ respectively, which was not statistically significant $(p>0.05)$.

In the academic year 2009/2010, the mean final exam score for the course "Ophthalmology and ophthalmic nursing" was $78 \%( \pm 13.2 \%)$ in the e-learning group and $74.9 \%( \pm 14.9 \%)$ in the traditional group. The difference was not statistically significant $(p>0.05)$. In $2010 / 2011$, the mean final exam score for this course was $79.4 \%( \pm 3.3 \%)$ and $81.6 \%( \pm 2.7 \%)$, respectively. Differences between these mean scores were statistically significant $(p<0.05)$.

In the study group (e-learning), the median final exam score for the course "Selected issues in visual rehabilitation" was $80 \%$ in 2009/2010 and $90 \%$ in 2010/2011. Differences between these scores were not statistically significant $(p>0.05)$. In the control group (traditional form of learning) the median final exam scores for this course during these years were: $70 \%$ and $85 \%$, respectively. These differences in scores were statistically significant $(p<0.001)$. The results obtained are presented in Figure 2.
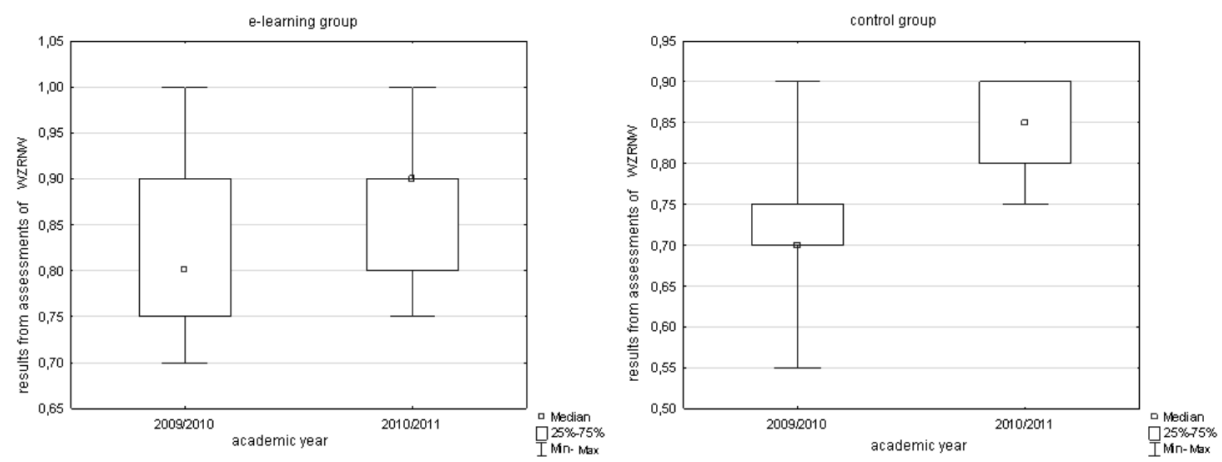

Figure 2. Final exam scores for the course "Selected issues in visual rehabilitation" in the academic years 2009-2011 in the study and control groups

A slightly better median final exam score in the study group may be explained by full-time access to didactic materials on the e-learning platform, which facilitated repeated readings and multiple analyses of didactic materials. In contrast, students from the control group based their studying on their own notes and information from the recommended literature list.

The change in the final exam scores for the course "Ophthalmology and ophthalmic nursing" during 2009-2011 (two academic years) is illustrated 
Wiesław Póljanowicz et al.
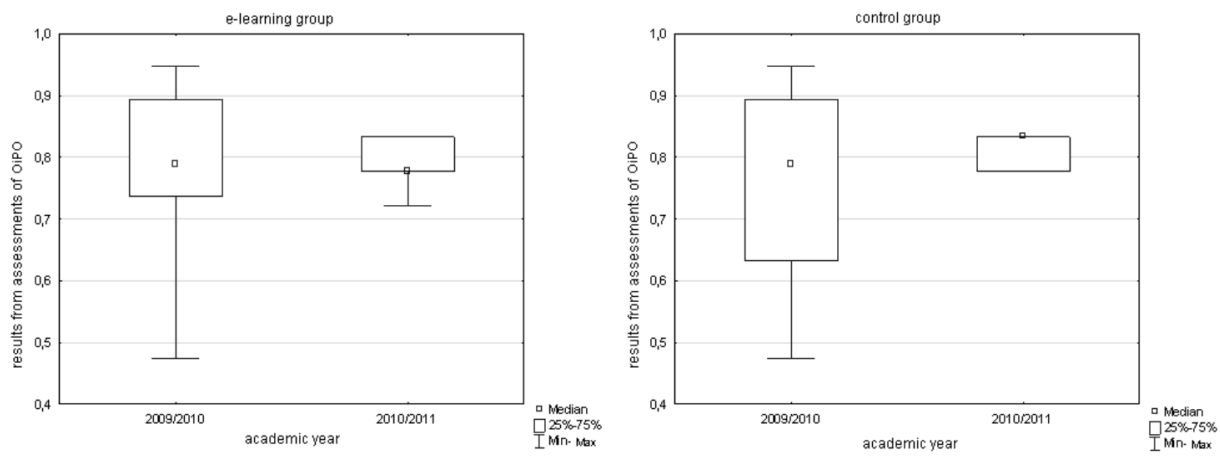

Figure 3. Final exam scores in the course "Ophthalmology and ophthalmic nursing" in the academic years 2009-2011 in the study and control groups

Table 3. Assessment of course organization in the academic years 2009-2011

\begin{tabular}{|c|c|c|c|c|c|c|c|c|c|}
\hline \multirow[b]{2}{*}{$\begin{array}{c}\text { Academic } \\
\text { year }\end{array}$} & \multirow[b]{2}{*}{ Course } & \multirow[b]{2}{*}{ Group } & \multicolumn{7}{|c|}{ Parameter } \\
\hline & & & $n$ & 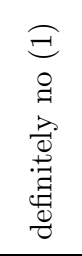 & 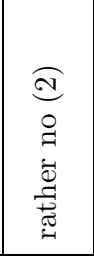 & 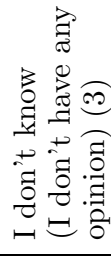 & 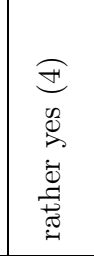 & 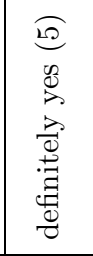 & $p$ \\
\hline \multirow{4}{*}{$2009 / 2010$} & \multirow{2}{*}{$\begin{array}{l}\text { Selected issues in } \\
\text { visual rehabilitation }\end{array}$} & Study & $\begin{array}{c}22 \\
100 \%\end{array}$ & $\begin{array}{c}0 \\
0 \%\end{array}$ & $\begin{array}{c}4 \\
18.2 \%\end{array}$ & $\begin{array}{c}2 \\
9.1 \%\end{array}$ & $\begin{array}{c}12 \\
54.5 \%\end{array}$ & $\begin{array}{c}4 \\
18.2 \%\end{array}$ & \multirow{2}{*}{0.531} \\
\hline & & Control & $\begin{array}{c}17 \\
100 \%\end{array}$ & $\begin{array}{c}0 \\
0 \%\end{array}$ & $\begin{array}{c}3 \\
17.6 \%\end{array}$ & $\begin{array}{c}0 \\
0 \%\end{array}$ & $\begin{array}{c}12 \\
70.6 \%\end{array}$ & $\begin{array}{c}2 \\
11.8 \%\end{array}$ & \\
\hline & \multirow{2}{*}{$\begin{array}{l}\text { Ophthalmology and } \\
\text { ophthalmic nursing }\end{array}$} & Study & $\begin{array}{c}22 \\
100 \%\end{array}$ & $\begin{array}{c}0 \\
0 \%\end{array}$ & $\begin{array}{c}3 \\
13.6 \%\end{array}$ & $\begin{array}{c}2 \\
9.1 \%\end{array}$ & $\begin{array}{c}14 \\
63.6 \%\end{array}$ & $\begin{array}{c}3 \\
13.6 \%\end{array}$ & \multirow{2}{*}{0.628} \\
\hline & & Control & $\begin{array}{c}17 \\
100 \%\end{array}$ & $\begin{array}{c}0 \\
0 \%\end{array}$ & $\begin{array}{c}3 \\
17.6 \%\end{array}$ & $\begin{array}{c}0 \\
0 \%\end{array}$ & $\begin{array}{c}12 \\
70.6 \%\end{array}$ & $\begin{array}{c}2 \\
11.8 \%\end{array}$ & \\
\hline \multirow{4}{*}{$2010 / 2011$} & \multirow{2}{*}{$\begin{array}{l}\text { Selected issues in } \\
\text { visual rehabilitation }\end{array}$} & Study & $\begin{array}{c}17 \\
100 \%\end{array}$ & $\begin{array}{c}0 \\
0 \%\end{array}$ & $\begin{array}{c}0 \\
0 \%\end{array}$ & $\begin{array}{c}0 \\
0 \%\end{array}$ & $\begin{array}{c}9 \\
52.9 \%\end{array}$ & $\begin{array}{c}8 \\
47.1 \%\end{array}$ & \multirow{2}{*}{0.138} \\
\hline & & Control & $\begin{array}{c}19 \\
100 \%\end{array}$ & $\begin{array}{c}0 \\
0 \%\end{array}$ & $\begin{array}{c}0 \\
0 \%\end{array}$ & $\begin{array}{c}2 \\
10.5 \%\end{array}$ & $\begin{array}{c}13 \\
68.4 \%\end{array}$ & $\begin{array}{c}4 \\
21.1 \%\end{array}$ & \\
\hline & \multirow{2}{*}{$\begin{array}{l}\text { Ophthalmology and } \\
\text { ophthalmic nursing }\end{array}$} & Study & $\begin{array}{c}17 \\
100 \%\end{array}$ & $\begin{array}{c}1 \\
5.9 \%\end{array}$ & $\begin{array}{c}2 \\
11.8 \%\end{array}$ & $\begin{array}{c}2 \\
11.8 \%\end{array}$ & $\begin{array}{c}9 \\
52.9 \%\end{array}$ & $\begin{array}{c}3 \\
17.6 \%\end{array}$ & \multirow{2}{*}{0.139} \\
\hline & & Control & $\begin{array}{c}19 \\
100 \%\end{array}$ & $\begin{array}{c}0 \\
0 \%\end{array}$ & $\begin{array}{c}0 \\
0 \%\end{array}$ & $\begin{array}{c}0 \\
0 \%\end{array}$ & $\begin{array}{c}12 \\
63.2 \%\end{array}$ & $\begin{array}{c}7 \\
36.8 \%\end{array}$ & \\
\hline
\end{tabular}


in Figure 3. The similar results prove that distance learning is comparable to the traditional approach.

Evaluation of the two-year study period shows that the organization of classes was rated positively by $31(80 \%)$ of the students in the elearning groups and $32(89 \%)$ of the students in the traditional groups. Only about $13 \%$ of students had a negative opinion on the organization of both forms of courses (Table 3). Differences on the Likert scale between the analyzed groups were not statistically significant $(p>0.05)$.

In the questionnaire the students were asked about course preparation as well as availability and relevance of the didactic content. 36 students from the e-learning group (91\%) and 32 students from control group (88\%) graded those issues positively (Table 4 ). In the academic year 2009/2010, differences between the responses in both groups were statistically significant $(p<0.05)$.

Table 4. Students' opinions on the preparation, availability and relevance of the didactic content of the courses in the years 2009-2011

\begin{tabular}{|c|c|c|c|c|c|c|c|c|c|}
\hline \multirow[b]{2}{*}{$\begin{array}{c}\text { Academic } \\
\text { year }\end{array}$} & \multirow[b]{2}{*}{ Course } & \multirow[b]{2}{*}{ Group } & \multicolumn{7}{|c|}{ Parameter } \\
\hline & & & $n$ & 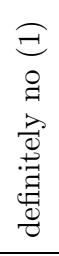 & 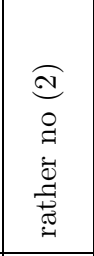 & 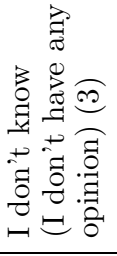 & 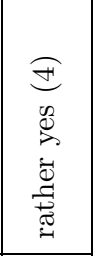 & 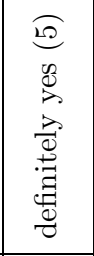 & $p$ \\
\hline \multirow{4}{*}{$2009 / 2010$} & \multirow{2}{*}{$\begin{array}{l}\text { Selected issues in } \\
\text { visual rehabilitation }\end{array}$} & Study & $\begin{array}{c}22 \\
100 \%\end{array}$ & $\begin{array}{c}0 \\
0 \%\end{array}$ & $\begin{array}{c}0 \\
0 \% \\
\end{array}$ & $\begin{array}{c}0 \\
0 \%\end{array}$ & $\begin{array}{c}14 \\
63.6 \%\end{array}$ & $\begin{array}{c}8 \\
36.4 \%\end{array}$ & \multirow{2}{*}{0.015} \\
\hline & & Control & $\begin{array}{c}17 \\
100 \%\end{array}$ & $\begin{array}{c}0 \\
0 \%\end{array}$ & $\begin{array}{c}1 \\
5.9 \%\end{array}$ & $\begin{array}{c}2 \\
11.8 \%\end{array}$ & $\begin{array}{c}14 \\
82.4 \%\end{array}$ & $\begin{array}{c}0 \\
0 \%\end{array}$ & \\
\hline & \multirow{2}{*}{$\begin{array}{l}\text { Ophthalmology and } \\
\text { ophthalmic nursing }\end{array}$} & Study & $\begin{array}{c}22 \\
100 \% \\
\end{array}$ & $\begin{array}{c}0 \\
0 \% \\
\end{array}$ & $\begin{array}{c}0 \\
0 \%\end{array}$ & $\begin{array}{c}0 \\
0 \% \\
\end{array}$ & $\begin{array}{c}14 \\
63.6 \% \\
\end{array}$ & $\begin{array}{c}8 \\
36.4 \% \\
\end{array}$ & \multirow{2}{*}{0.015} \\
\hline & & Control & $\begin{array}{c}17 \\
100 \%\end{array}$ & $\begin{array}{c}0 \\
0 \%\end{array}$ & $\begin{array}{c}1 \\
5.9 \% \\
\end{array}$ & $\begin{array}{c}2 \\
11.8 \%\end{array}$ & $\begin{array}{c}14 \\
82.4 \%\end{array}$ & $\begin{array}{c}0 \\
0 \%\end{array}$ & \\
\hline \multirow{4}{*}{$2010 / 2011$} & \multirow{2}{*}{$\begin{array}{l}\text { Selected issues in } \\
\text { visual rehabilitation }\end{array}$} & Study & $\begin{array}{c}17 \\
100 \%\end{array}$ & $\begin{array}{c}0 \\
0 \%\end{array}$ & $\begin{array}{c}0 \\
0 \%\end{array}$ & $\begin{array}{c}1 \\
5.9 \%\end{array}$ & $\begin{array}{c}10 \\
58.8 \%\end{array}$ & $\begin{array}{c}6 \\
35.3 \%\end{array}$ & \multirow{2}{*}{0.78} \\
\hline & & Control & $\begin{array}{c}19 \\
100 \%\end{array}$ & $\begin{array}{c}0 \\
0 \%\end{array}$ & $\begin{array}{c}0 \\
0 \%\end{array}$ & $\begin{array}{c}2 \\
10.5 \%\end{array}$ & $\begin{array}{c}12 \\
63.2 \%\end{array}$ & $\begin{array}{c}5 \\
26.3 \%\end{array}$ & \\
\hline & \multirow{2}{*}{$\begin{array}{l}\text { Ophthalmology and } \\
\text { ophthalmic nursing }\end{array}$} & Study & $\begin{array}{c}17 \\
100 \%\end{array}$ & $\begin{array}{c}0 \\
0 \%\end{array}$ & $\begin{array}{c}2 \\
11.8 \%\end{array}$ & $\begin{array}{c}3 \\
17.6 \%\end{array}$ & $\begin{array}{c}6 \\
35.3 \%\end{array}$ & $\begin{array}{c}6 \\
35.3 \%\end{array}$ & \multirow{2}{*}{0.06} \\
\hline & & Control & $\begin{array}{c}19 \\
100 \%\end{array}$ & $\begin{array}{c}0 \\
0 \%\end{array}$ & $\begin{array}{c}0 \\
0 \%\end{array}$ & $\begin{array}{c}0 \\
0 \%\end{array}$ & $\begin{array}{c}13 \\
68.4 \%\end{array}$ & $\begin{array}{c}6 \\
31.6 \%\end{array}$ & \\
\hline
\end{tabular}


Wiestaw Póljanowicz et al.

The students were asked whether the implemented curriculum enriched their knowledge and skills. 34 students in the e-learning group (86\%) and 30 in the control group (83\%) responded affirmatively (rather yes, definitely yes) (Table 5). Differences between the analyzed groups, however, were not statistically significant $(p>0.05)$.

Table 5. Opinions on the prepared courses in the years 2009-2011 (acquired knowledge and skills)

\begin{tabular}{|c|c|c|c|c|c|c|c|c|c|}
\hline \multirow[b]{2}{*}{$\begin{array}{c}\text { Academic } \\
\text { year }\end{array}$} & \multirow[b]{2}{*}{ Course } & \multirow[b]{2}{*}{ Group } & \multicolumn{7}{|c|}{ Parameter } \\
\hline & & & $n$ & 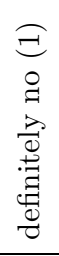 & 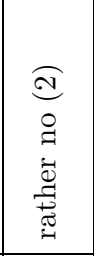 & 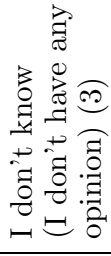 & 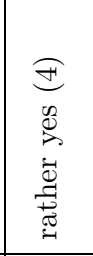 & $\begin{array}{l}20 \\
0 \\
0 \\
0 \\
0 \\
0 \\
0 \\
.0 \\
.01 \\
0 \\
0\end{array}$ & $p$ \\
\hline \multirow{4}{*}{$2009 / 2010$} & \multirow{2}{*}{$\begin{array}{l}\text { Selected issues in } \\
\text { visual rehabilitation }\end{array}$} & Study & $\begin{array}{c}22 \\
100 \%\end{array}$ & $\begin{array}{c}0 \\
0 \%\end{array}$ & $\begin{array}{c}1 \\
4.5 \% \\
\end{array}$ & $\begin{array}{c}2 \\
9.1 \%\end{array}$ & $\begin{array}{c}13 \\
59.2 \%\end{array}$ & $\begin{array}{c}6 \\
27.3 \%\end{array}$ & \multirow{2}{*}{0.122} \\
\hline & & Control & $\begin{array}{c}17 \\
100 \%\end{array}$ & $\begin{array}{c}0 \\
0 \%\end{array}$ & $\begin{array}{c}2 \\
11.8 \%\end{array}$ & $\begin{array}{c}2 \\
11.8 \% \\
\end{array}$ & $\begin{array}{c}13 \\
76.5 \%\end{array}$ & $\begin{array}{c}0 \\
0 \%\end{array}$ & \\
\hline & \multirow{2}{*}{$\begin{array}{l}\text { Ophthalmology and } \\
\text { ophthalmic nursing }\end{array}$} & Study & $\begin{array}{c}22 \\
100 \% \\
\end{array}$ & $\begin{array}{c}0 \\
0 \%\end{array}$ & $\begin{array}{c}1 \\
4.5 \%\end{array}$ & $\begin{array}{c}2 \\
9.1 \%\end{array}$ & $\begin{array}{c}14 \\
63.3 \%\end{array}$ & $\begin{array}{c}5 \\
22.7 \%\end{array}$ & \multirow{2}{*}{0.186} \\
\hline & & Control & $\begin{array}{c}17 \\
100 \%\end{array}$ & $\begin{array}{c}0 \\
0 \%\end{array}$ & $\begin{array}{c}2 \\
11.8 \%\end{array}$ & $\begin{array}{c}2 \\
11.8 \%\end{array}$ & $\begin{array}{c}13 \\
76.5 \%\end{array}$ & $\begin{array}{c}0 \\
0 \%\end{array}$ & \\
\hline \multirow{4}{*}{$2010 / 2011$} & \multirow{2}{*}{$\begin{array}{l}\text { Selected issues in } \\
\text { visual rehabilitation }\end{array}$} & Study & $\begin{array}{c}17 \\
100 \%\end{array}$ & $\begin{array}{c}0 \\
0 \%\end{array}$ & $\begin{array}{c}0 \\
0 \%\end{array}$ & $\begin{array}{c}0 \\
0 \%\end{array}$ & $\begin{array}{c}7 \\
41.2 \% \\
\end{array}$ & $\begin{array}{c}10 \\
58.8 \%\end{array}$ & \multirow{2}{*}{0.212} \\
\hline & & Control & $\begin{array}{c}19 \\
100 \% \\
\end{array}$ & $\begin{array}{c}0 \\
0 \% \\
\end{array}$ & $\begin{array}{c}2 \\
10.5 \% \\
\end{array}$ & $\begin{array}{c}2 \\
10.5 \% \\
\end{array}$ & $\begin{array}{c}8 \\
42.1 \% \\
\end{array}$ & $\begin{array}{c}7 \\
36.8 \% \\
\end{array}$ & \\
\hline & \multirow{2}{*}{$\begin{array}{l}\text { Ophthalmology and } \\
\text { ophthalmic nursing }\end{array}$} & Study & $\begin{array}{c}17 \\
100 \%\end{array}$ & $\begin{array}{c}0 \\
0 \%\end{array}$ & $\begin{array}{c}2 \\
11.8 \%\end{array}$ & $\begin{array}{c}3 \\
17.6 \%\end{array}$ & $\begin{array}{c}8 \\
47.1 \%\end{array}$ & $\begin{array}{c}4 \\
23.5 \%\end{array}$ & \multirow{2}{*}{0.081} \\
\hline & & Control & $\begin{array}{c}19 \\
100 \%\end{array}$ & $\begin{array}{c}0 \\
0 \%\end{array}$ & $\begin{array}{c}0 \\
0 \%\end{array}$ & $\begin{array}{c}0 \\
0 \%\end{array}$ & $\begin{array}{c}11 \\
57.9 \%\end{array}$ & $\begin{array}{c}8 \\
42.1 \%\end{array}$ & \\
\hline
\end{tabular}

The obtained results lead to the conclusion that e-learning can be a good way to supplement traditional methods. In some forms, such as lectures or seminars, it can successfully replace traditional classes. Setting e-learning courses available to students in other medical fields is advisable and justified because of the intensity of the different types of activities demanded of these students, i.e. lectures, seminars, practical or lab classes, clinic hours or internships. 
The students' opinions indicate a high level of preparation of teaching materials and course organization. The popularity of distance learning may result from interactive access to the information contained in the online course (lesson, quiz, task, forum) or just multiple access to the course material resources. A student can repeatedly refer to the previously analyzed issue, learn it better, acquire knowledge on the topic, and independently test their knowledge on the subject (Douglas et al., 2004; Półjanowicz et al., 2009; Półjanowicz et al., 2010).

As a result of online learning, the university teacher has a new role as a kind of mentor. Using the prepared teaching materials (Figure 4) and tests (Figure 5), the teacher can conveniently check the students' knowledge. Both the teacher and student are able to see test results immediately (Rice, 2010).

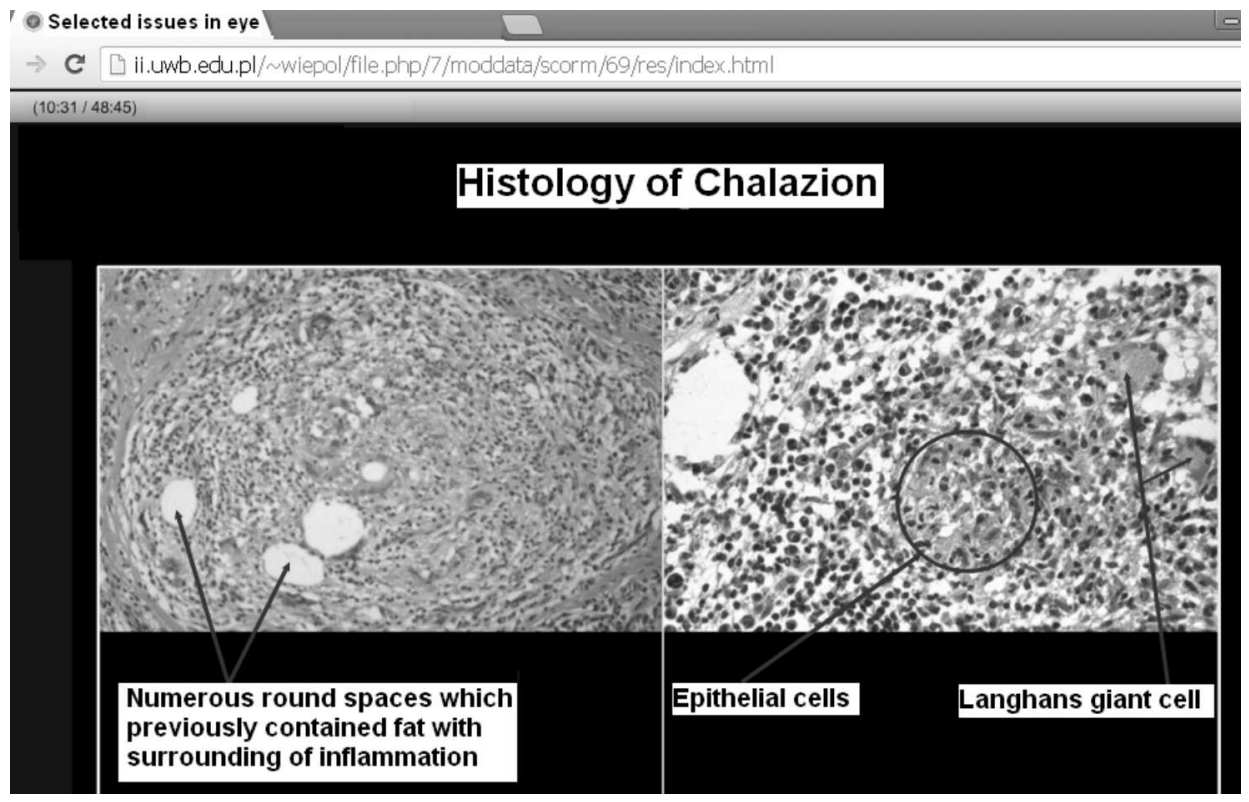

Figure 4. Screenshot of multimedia teaching materials on visual rehabilitation

Pilot studies conducted among students majoring in computer sciences at the School of Humanities and Journalism and medicine at the Medical University in Poznan in the academic year 2011/2012 to assess the relevance of e-learning materials and electronic examination of students (Roszak et al., 2013a; Roszak et al., 2013b) confirmed a high evaluation of e-learning methods and tools in the teaching process. 
Wiesław Póljanowicz et al.

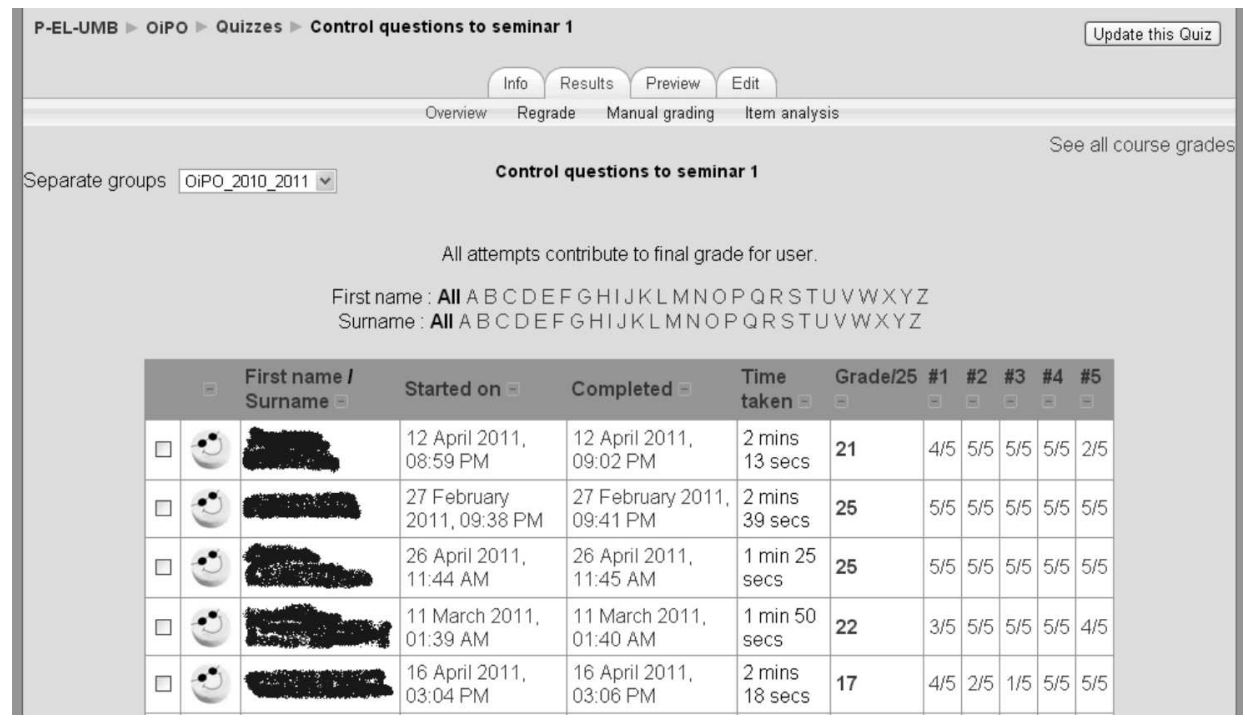

Figure 5. Screenshot of quiz assessing student knowledge in the course "Ophthalmology and ophthalmic nursing"

Studies performed at Maria Curie-Skłodowska University of Lublin on Logopedy with Audiology Faculty (in cooperation with the Institute of Physiology and Pathology of Hearing, Warsaw) confirmed that the majority of students evaluated e-learning systems positively (as very good - $64 \%$ and good $-31 \%$ of students), regarding quality and accessibility of didactic materials. Approximately $68 \%$ of students reported that e-learning is an effective method of education while nearly $86 \%$ reported that electronic knowledge assessment tests are a great advantage of distance learning. However, the major advantages of e-learning are: all day access to didactic materials (90\%), saving time (98\%), and individualization of the teaching process $(71 \%)$. Moreover, according to academic teachers from the Institute of Physiology and Pathology of Hearing in Warsaw, e-learning allows time spent on educational activities to be reduced without a decrease in learning quality (Bombol-Lagha et al., 2012).

Our study included a group of 75 nursing students enrolled in the courses "Selected issues in visual rehabilitation" and "Ophthalmology and ophthalmic nursing" in the years 2009-2011 using e-learning and traditional learning methods. The positive results produced by a comparison of these groups confirmed the assumption that the use of e-learning would not worsen the state of professional knowledge, student satisfaction, or learning effectiveness compared with students attending traditional classes. 
In connection with the development of Internet access and mobile devices, distance education is and will continue to become more and more popular and natural. Students enrolling in virtual courses are not bound to the place or time of their implementation. They can acquire knowledge at their own time and save time on commuting to the university. Virtual systems of consultation with the instructor (forums, FAQ, chat) do not leave the student alone in the jungle of available information. Students have more flexibility in content implementation; however, this is directly connected with more self-discipline, conscientiousness and responsibility on the part of the learners (Douglas et al., 2004; Selvi, 2010; Shroff et al., 2007; $\mathrm{Wu}$ et al., 2010). The next step to increase the attractiveness of distance learning is to personalize e-learning courses according to individual learning style. This may increase student satisfaction and knowledge gained.

\section{Conclusions}

The results obtained during this study allow us to conclude that elearning is not inferior to traditional teaching methods for the courses "Selected issues in visual rehabilitation" and "Ophthalmology and ophthalmic nursing" for nursing majors.

The study and statistical analysis allow us to conclude that course organization was rated positively by $80 \%$ of the students in the e-learning groups and $89 \%$ in the traditional groups. $91 \%$ of the students in the elearning groups and $88 \%$ in the traditional groups rated course preparation as well as availability and relevance of the didactic content positively. In addition, $86 \%$ of students in the e-learning groups and $83 \%$ in the traditional groups rated their acquisition of knowledge and skills positively.

The multimedia, e-learning teaching materials, available to students throughout the semester, enabled more flexible learning opportunities and preparation for the final exam, while simultaneously allowing students to widen and assimilate knowledge of ophthalmology and visual rehabilitation.

\section{R E F E R E N C E S}

Allan, B. (2007). Time to learn? E-learners' experiences of time in virtual learning communities. Management Learning, 38, 557-572.

Arbaugh, J. B., Desai, A., Rau, B., \& Sridhar, B. S. (2010). A review of research on online and blended learning in the management disciplines: 1994-2009. Organization Management Journal, 7(1), 39-55. 
Wiestaw Póljanowicz et al.

Bombol-Lagha, M., \& Śliwa, L. (2012). Wyniki wdrożenia formy blended learning na kierunku Logopedia $\mathrm{z}$ audiologia na Uniwersytecie Marii CurieSkłodowskiej. E-mentor, 5(47), 57-61.

Bramley, P. (2001). Ocena efektywności szkoleń. Kraków: Dom Wydawniczy ABC.

Douglas, D. E., \& van der Vyver, G. (2004). Effectiveness of e-learning course materials for learning database management systems: an experimental investigation. Journal of Computer Information Systems, 44(4), 41-48.

Piskurich, G. M. (2003). The AMA Handbook of E-Learning, Effective Design, Implementation, and Technology Solutions. New York: AMACOM.

Półjanowicz, W., Latosiewicz, R., Niewiński, A., \& Milewski, R. (2009). E-learning in students education in Medical University of Bialystok. Bio-Algorithms and Med-Systems, 5(9), 111-115.

Półjanowicz, W., Latosiewicz, R., Kulesza-Brończyk, B., Piekut, K., Kalisz, A., Piechocka, D. I., \& Terlikowski, S. J. (2010). Comparative analysis of elearning and traditional teaching methods in the field of nursing in the Medical University of Bialystok. The chosen aspects of woman and family's health, 2, 94-104.

Rice, W. H. (2010). Tworzenie serwisów e-learningowych z Moodle 1.9. Gliwice: Helion.

Roszak, M., Kołodziejczak, B., Ren-Kurc, A., Kowalewski, W., \& Bręborowicz, A. (2013a). Learning Content Development System (LCDS) jako narzędzie tworzenia materiałów powtórkowych. E-mentor, 1(48), 40-46.

Roszak, M., Kołodziejczak, B., Kowalewski, W., \& Ren-Kurc, A. (2013b). Standard Question and Test Interoperability (QTI) - ewaluacja wiedzy studenta. Ementor, 2(49), 35-40.

Selvi, K. (2010). Motivating factors in online courses. Procedia - Social and Behavioral Sciences, 2(2), 819-824.

Shroff, R. H., Vogel, D. R., Coombes, J., \& Lee, F. (2007). Student E-Learning Intrinsic Motivation: A Qualitative Analysis. Communications of the Association for Information Systems, 19(12), 241-260.

Smith, G. G., Heindel, A. J. \& Torres-Ayala, A. T. (2008). E-learning commodity or community: Disciplinary differences between online courses. The Internet and Higher Education, 11(1), 152-159.

Waćkowski, K., \& Chmielewski, J. M. (2007). Rola standaryzacji platform w elearningu. E-mentor, 2(19), 25-32.

Wu, W. C., \& Hwang, L. Y. (2010). The effectiveness of e-larning for blended courses in colleges: a multi-level empirical study. International Journal of Electronic Business Management, 8(4), 301-310. 